\title{
Monitoring Long-term Mangrove Shoreline Changes along the Northern Coasts of the Persian Gulf and the Oman Sea
}

\author{
Davood Mafi-Gholami ${ }^{\text {a*}}$, Masoomeh Baharlouii ${ }^{\text {a }}$ \\ ${ }^{a}$ Department of Forest Sciences, Faculty of Natural Resources and Earth Sciences, Shaherkord University, Shaherkord, Iran
}

\begin{abstract}
Generally, investigating changes in mangrove shorelines is an important step to evaluate whether mangrove ecosystems are expanding or contracting. In this study, the rates of change of mangrove boundaries were investigated along the coasts of the Persian Gulf and the Oman Sea, over a 30-year period. Seaward edges of mangrove forests were extracted from Landsat images of the years 1986, 2000 and 2016 and the Digital Shoreline Analysis System (DSAS) Software was used to implement the Linear Regression Rate (LRR) method to quantify the rates of boundary changes. On average, areas that experienced boundary expansion progressed by $2.55 \mathrm{~m} \mathrm{yr}^{-1}$ and those that experienced contraction regressed by $-0.38 \mathrm{~m} \mathrm{yr}^{-1}$. The maximum rate of expansion was $25.91 \mathrm{~m} \mathrm{yr}^{-1}$ and the maximum rate of contraction was $-22.45 \mathrm{~m} \mathrm{yr}^{-1}$. Mangroves located on the coasts of the Persian Gulf exhibited differential rates of progression and regression at their borders, with expansion rates increasing in an eastward direction toward the coasts of the Oman Sea. However, on the eastern coasts of the Oman Sea, mangroves are characterized by contraction and erosion.
\end{abstract}

\author{
Keywords: \\ Mangroves; \\ RS; \\ Progression and Regression; \\ Persian Gulf; \\ Oman Sea. \\ Article History: \\ Received: 05 February 2019 \\ Accepted: 29 March 2019
}

\section{1- Introduction}

Among the natural sub-systems located along the world's shorelines, mangrove forests straddle both marine and terrestrial ecosystems and provide a diverse range of goods and services such as the provision of wood and marine products, prevention of damage caused by storms, provision of flood control, protection of coastlines, and control of coastal erosion, waste assimilation, recreation, and transportation required by coastal communities [1-5]. For thousands of years, these forests have played a major role in the economies of human societies, sustaining people's livelihoods [6, 7]. Despite the importance of these ecosystem services for meeting human needs, degradation and loss of these unique coastal habitats around the world have been intensified over the past three decades, so that more than 50\% of the world's mangrove forests have already been destroyed and the trend is still continuing [8]. Loss of a wide range of goods and services provided by this ecosystem as well as enhanced risk to mangrove-dependent human communities are the direct results of the destruction and loss of mangrove ecosystems [9-12]. This calls for the development of effective planning and management strategies to conserve and restore mangrove ecosystems, which has become elevated to one of the main objectives for decision makers and managers of natural resources responsible for sustaining mangrove ecosystems. One way to achieve these goals is to first assess whether, and if so, how mangrove shorelines have changed over time. Such a dynamic change of coastal areas would be a powerful indicator for the degree of vulnerability and responsiveness of mangroves to stresses induced by climate change [13-15].

Mangroves on the coast of the Persian Gulf and the Oman Sea are one of the most important remaining mangrove habitats in the Middle East and cover an area of approximately $427 \mathrm{~km}^{2}$ along the coasts of Iran, Saudi Arabia, Kuwait, UAE, Bahrain and Qatar [16, 17]. A significant part $\left(\sim 192 \mathrm{~km}^{2}\right)$ of these mangroves is located on the coasts of Iran and, due to its high-value status for ecosystem services and functions, is an integral part of the global network of the Man and the Biosphere reserve system. In spite of their considerable importance at the international level, mangrove forests of

\footnotetext{
*CONTACT: D.mafigholami@sku.ac.ir

DOI: http://dx.doi.org/10.28991/esj-2019-01172

(C) This is an open access article under the CC-BY license (https://creativecommons.org/licenses/by/4.0/).
} 
Iran are still subjected to ongoing natural and human destructive factors such as over-exploitation of mangrove branches, unplanned tourism, industrial and mining development, aquaculture development, introduction of non-native species (e.g., black rat), over-exploitation of aquatics, discharge of industrial and urban waste into forests, oil pollution, successive droughts, lack of rainfall, and reduction of water discharge and nutrient-feeding sediments [18, 19]. These stresses and disturbances have caused undesirable changes in the growth and development of mangroves and disruptions in coastal sediment dynamics, which can further increase the vulnerability of mangrove forests to other climatic and hydrological hazards [20-22]. Decreased area and regression of mangrove boundaries can result in a decreased adaptive capacity and an increased vulnerability to current and future natural and human stresses and disturbances [23]. These potentially adverse effects highlight the importance of evaluating changes in mangrove shorelines to better predict the future vulnerability of mangroves. Therefore, the aim of this study is report on changes in mangrove shorelines in the coastal areas of the Persian Gulf and the Oman Sea over a period of 30 years.

\section{1-1-Research History}

Satellite images and geographic information system (GIS) have been extensively used to monitor spatial and temporal changes over time of mangrove forests and other habitats [13, 14, 24-37]. In this regard, the Digital Shoreline Analysis System (DSAS) is one of the ArcMap tools that have been prepared for automatic or supervised measurements of changes in coastlines [38]. In the DSAS system, the user measures the boundary changes at different time periods using a defined coastal base-line and determines a set of transects from this line perpendicular to this base line toward the inshore and off-shore areas [39]. Due to the efficiency and accuracy of the software, this approach has been widely used to study changes of the world's coastlines as well as the borders of mangrove forests (Table 1).

Table 1. Examples of studies carried out using DSAS to evaluate the rate of change in coastlines and borders of mangrove forests around the world

\begin{tabular}{|c|c|c|c|}
\hline No. & Study area & Period & References \\
\hline 1 & Barrio Islote, Arecibo, Puerto Rico & $1950-2010$ & Thieler and Danforth [40] \\
\hline 3 & California coast, USA & $1800 s-2002$ & Hapke et al. [41] \\
\hline 4 & Mad Island Marsh Preserve, Texas, USA & 1995-2005 & Mangham and Williams [42] \\
\hline 5 & California coast, USA & 1920-2002 & Hapke and Reid [43] \\
\hline 6 & Accra, Ghana & 1904-2002 & Appeaning Addo et al. [44] \\
\hline 7 & Phan Thiet coastal area, Vietnam & 1973-2002 & Thao et al. [45] \\
\hline 8 & Sefton Coast, UK & $1955-2005$ & Esteves et al. [46] \\
\hline 9 & California coast, USA & $1800 s-2001$ & Hapke et al. [47] \\
\hline 11 & Cedar Island, North Carolina, USA & 1958-1998 & Lisa et al. [48] \\
\hline 12 & New England and mid-Atlantic coasts, USA & $1800 s-2000 s$ & Hapke et al. [49] \\
\hline 15 & Sheltered coastlines in Neuse River estuary, USA & $1958-1998$ & Cowart et al. [50] \\
\hline 16 & Sundarbans coastline, India and Bangladesh & $1973-2010$ & Rahman et al. [51] \\
\hline 17 & Sele Plain coastline, Italy & $1870-2009$ & Alberico et al. [52] \\
\hline 18 & Coastal Ramsar wetlands of Turkey, Turkey & 1972-2009 & Kuleli et al. [53] \\
\hline 19 & Coast between Kanyakumari and Tuticorin, India & 1999-2009 & Sheik and Chandrasekar [54] \\
\hline 20 & Mangroves of Douala Estuary, Cameroon & 1975-2007 & Ellison and Zhou [23] \\
\hline 21 & Vedaranyam coast, Tamil Nadu, India & 1930-2005 & Natesan et al. [55] \\
\hline 22 & Kien Giang coast, Vietnam & 2003-2009 & Hai-Hoa et al. [56] \\
\hline 23 & Coast of Bangladesh & 1989-2009 & Sarwar and Woodroffe [57] \\
\hline 24 & Mangroves of Mui Ca Mau, Vietnam & $1953-2011$ & Tran Thi et al. [58] \\
\hline 25 & Coastline around Denmark & $1862-2005$ & Kabuth et al. [59] \\
\hline 26 & Niger delta, Africa & $1986-2013$ & Kuenzer et al. [60] \\
\hline 27 & western Yukon coast, Canada & $1951-2009$ & Konopczak et al. [61] \\
\hline
\end{tabular}

Although various studies have measured the advance and retreat of the coastlines and mangrove boundaries around the world, no studies have been done on the status of mangroves on the coasts of the Persian Gulf and the Oman Sea to test whether they are progressing or regressing. Therefore, the present study reports the rate of progression (process of sedimentation) and regression (process of erosion) of mangrove forests on the coasts of Iran over a period of 30 years using Landsat images for the years 1986, 2000 and 2016 and the DSAS software. 


\section{2- Methods}

\section{2-1- Study Area}

Our study area consists of mangrove forests located in the Hormozgan province on the northern coasts of the Persian Gulf and the Oman Sea. The size of the area is 10700 ha and is located in the jurisdiction of seven towns (i.e., Jask, Sirik, Minab, Bandar Abbas, Khamir, Qeshm and Bandar Lengeh). Natural mangrove forests in coastal areas of Hormozgan stretch from $25^{\circ} 34^{\prime} 13^{\prime \prime} \mathrm{N}$ in Gabrig (Jask town) to $27^{\circ} 10^{\prime} 54^{\prime \prime}$ in Koulaghan (Bandar Abbas town)

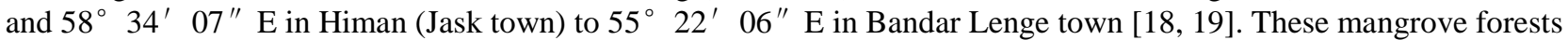
consist of two mangrove species, i.e., Harra (Avicennia marina) and Chandal (Rhizophora mucronata), that occupy the largest area of these forests in Iran. These mangroves are comprised of unmixed, irregular and uneven aged Avicennia associations and, in the Sirik habitat, Rhizophora mixed with Avicennia species [18]. These forests grow mainly on loamy surface soil consisting of clay-loam to loam-silt-clay sub-surface textures, with proportions of soil organic matter varying from $0.33 \%$ to $4.43 \%$, an average of $1.2 \%$ and relatively higher proportions in the sub-surface soil than in the surface soil [19]. In this study, the rate of progression and regression of mangrove forests along the coasts was based on the sediment state (i.e., erosion or accretion) in coastal mangrove forest areas for which satellite images existed. Thus, mangrove forests were divided into 10 zones and the rate of change of mangrove forest boundaries was studied (Figure 1).

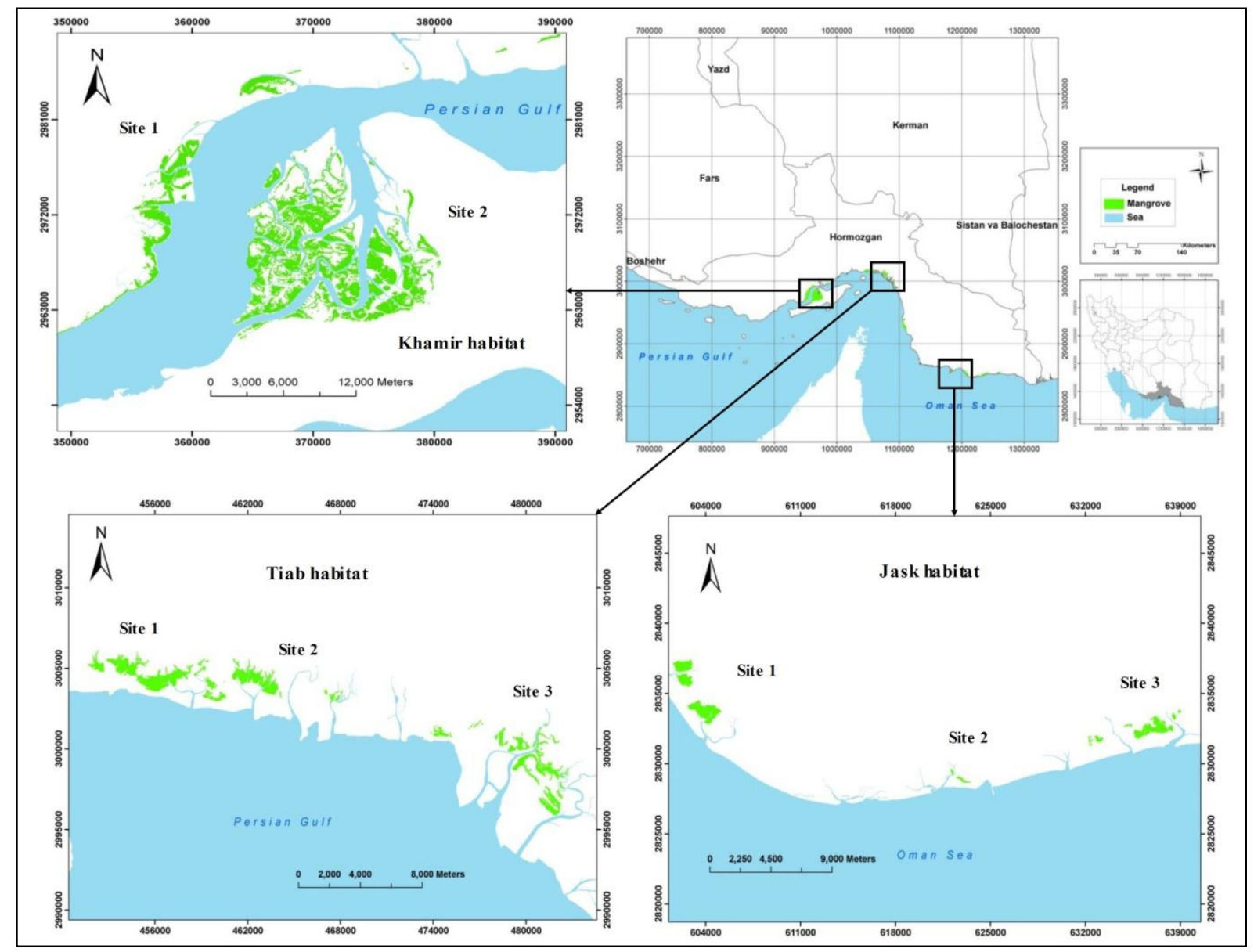

Figure 1. Geographic location of mangrove habitats on the northern coasts of the Persian Gulf and the Oman Sea

\section{2-2- Processing of Satellite Images}

The Landsat images of the years 1986, 2000 and 2016 were used to analyze the rate of progression and/or regression of mangrove forests over a period of 30 years. Images were selected for these years because they achieved a good spatial coverage during the period, avoiding potential skewness issues when running regression models [23, 62]. It should be noted that the limited availability of satellite images with higher resolution obliged us to choose Landsat images for this work. Since cloud cover reduces the image quality and causes errors in detecting the phenomena of interest in the images, we first examined a larger number of images in the Landsat satellite archives and used only images without cloud cover. To determine the mangrove boundaries as exactly as possible, we only used images taken at a time when the sea level was at low tide. Since determining the exact boundaries of mangrove forests is a critical step, images with very high geometric precision are required. Although Landsat $\mathrm{C}$ images are generally characterized by good geometric precision, to ensure maximum possible accuracy, a total of 250 ground control points with good spatial distribution throughout the 
study area were recorded using GPS units. Landsat C images of 2016 were then georeferenced with the use of IDRISI software, resulting in a root mean square error lower than one pixel (RMS $=0.143$ ). Finally, the corrected Landsat $C$ images were then used for geometric correction of the Landsat TM images taken in 1986 and 2000. None of the RMS values of the Landsat TM images in any of the corrections was higher than 0.18. All images were geo-referenced to the UTMWGS-1984 Zone 40N projection and datum.

Considering the resolution of the images available and following studies by Gilman and Ellison [14], Ellison and Zouh [23] and Tran Thi et al. [58], the closed-canopy edge of the boundary of the mangrove forests was considered as the off-shore (marine) boundary; single trees and seedlings located beyond this edge were excluded from the analysis of site boundaries. To ensure separation of mangroves from surrounding waters and upland areas when drawing the final boundaries for each site, we used the NDVI vegetation index that is considered one of the best and most widely used indices for quick and easy distinction of green vegetation from other land cover [63, 64]. After computing the NDVI, the off-shore (marine) borders of the mangroves were manually digitized using precise visual interpretation on a scale of 1: 10,000 and vetted with a team of experts familiar with these areas. Finally, the off-shore borders of the mangrove sites were identified in the images of 1986, 2000 and 2016 and overlayed on the Landsat images.

\section{2-3- Social Survey}

Social surveys were conducted that consisted of face to face interviews with families that live in the villages adjacent to the mangroves and with experts from the Department of Natural Resources of the province. Given that the purpose of the interview was to obtain the views on reasons that may explain potential changes in the mangrove ecosystem, only people with residence histories of more than 30 years in the area were interviewed. Accordingly, 25 people aged from 50 to 65 years were interviewed and their views recorded.

\section{2-4- Calculating the Change Rate of Mangrove Boundaries Using DSAS}

The progression and regression rates of mangroves is based on the changes over time of the mangrove boundary position relative to a baseline position demarcated on 2701 transects that were $30 \mathrm{~m}$ apart and ran perpendicular to the boundary edges. The transects and the baselines were drawn manually using the DSAS software, taking into account the general layout of each site and boundary, and by using the mapped buffer for mangrove boundaries in the Landsat images of the year 2000 (see [23, 57]). The calculation of the rate of progression (sedimentation) or regression (erosion) can be done with various statistical methods including end point rate (EPR), average of rates (AOR), minimum description length (MDL), jackknifing (JK), linear regression rate (LRR), weighted least squares (WLS) least absolute deviation (LAD) and weighted least absolute deviation (WLAD) [40, 53, 54, 62, 65-69]. Among these methods, the LRR statistical method is most widely used and allows assessing changes in the coastlines and borders of ecosystems at different times (more than 2 periods) [57, 58] Using this method, we estimated the average rates of progression and regression of mangroves using the position of the border-lines relative to the baseline. Positive LRR values calculated by DSAS indicate a progression of the borders (sedimentation and expansion of mangroves) whereas negative LRR values indicate a regression of the borders (erosion and contraction of mangroves) over the 30-year period.

\section{3- Results}

Spatially explicit analyses of boundary changes of mangroves over time is a powerful tool that can help allocate limited resources through planning and implementation of conservation measures to vulnerable areas where man groves are particularly threatened by natural and human-induced hazards $[23,70,71]$. The calculated LRR values of changes in boundaries varied among and within regions and revealed that some borders of the mangroves progressed toward the sea (sedimentation), while others regressed (erosion) and led to boundary contractions and loss of mangroves at the seaedge. A total of 1424 of 2701 transects (53\%) with positive LRR values had boundaries that progressed toward the sea, while 1174 transects $(43 \%)$ had negative LRR values and boundaries regressed inland (Table 2). Of the 31 studied sites in 10 zones, 11 sites (35\%) exhibited an overall boundary contraction, with generally more transects showing regression than progression. Zone $1-$ Site 1 had the highest proportion of transects $(86 \%)$ with boundary regression that changed on average by $-1.06 \pm 0.23 \mathrm{~m} \mathrm{yr}^{-1}$, which represented the greatest regression or erosion rate among all sites. The mean rates of progression and regression in mangroves of the Hormozgan coasts (Persian Gulf and Oman Sea) were 2.55 and $-0.38 \mathrm{~m} \mathrm{yr}^{-1}$, respectively. Zone 1 that has a marginal length of approximately $71 \mathrm{~km}$ and extends from the Pohl coast to the Mehran River estuary, experienced contraction of boundaries on 707 of $1450(49 \%)$ transects; 675 (47\%) transects expanded their boundaries. Sites 1-3 and 5-6 had the most transects (53\%) with boundary contraction, resulting in overall boundary contractions at each site (Table 2). In Zone 1, the greatest mean boundary expansion was $10.46 \mathrm{~m} \mathrm{yr}^{-1}$ (Site 14); the greatest mean boundary contraction was $-6.35 \mathrm{~m} \mathrm{yr}^{-1}$ (Site 7). The number of transects with boundary contraction gradually decreased and the number of transects with boundary expansion gradually increased from Site 1 to Site 15; similarly, a trend of increasing rates of sedimentation is seen to reverse from predominant erosion between Sites 1 and 8 to sedimentation and positive average rates of boundary changes between Sites 10 and 15 (Table 2). Site 13 that has a marginal length of $4.26 \mathrm{~km}$ expanded boundaries on all transects and exhibited the highest expansion rate $(5.9 \pm 2.57 \mathrm{~m}$ 
$\mathrm{yr}^{-1}$ ) among all sites of Zone 1. Similarly, Sites 12, 14 and 15, which resemble islands, expanded the boundaries of mangroves (Table 2 and Figure 2).

Table 2. Rates of change of mangrove shorelines in ten zones across the study area.

\begin{tabular}{|c|c|c|c|c|c|c|c|}
\hline \multirow{2}{*}{ Zone } & \multirow{2}{*}{ Site } & \multirow{2}{*}{$\begin{array}{l}\text { Number of } \\
\text { Transects }\end{array}$} & \multicolumn{2}{|c|}{ Sign of LRR } & \multirow{2}{*}{$\begin{array}{c}\text { Mean of mangrove } \\
\text { shoreline change } \\
\left(\mathbf{m ~ y r}^{-1}\right)\end{array}$} & \multirow{2}{*}{$\begin{array}{c}\text { Maximum of mangrove } \\
\text { shoreline change } \\
\left(\mathrm{m} \mathrm{yr}^{-1}\right)\end{array}$} & \multirow{2}{*}{$\begin{array}{c}\text { Minimum of mangrove } \\
\text { shoreline change } \\
\left(\mathrm{m} \mathrm{yr}^{-1}\right)\end{array}$} \\
\hline & & & Positive & Negative & & & \\
\hline \multirow{15}{*}{1} & 1 & 174 & 18 & 149 & $-1.06 \pm 0.23$ & 0.45 & -4.15 \\
\hline & 2 & 53 & 22 & 25 & $-0.33 \pm 0.11$ & 0.98 & -2.79 \\
\hline & 3 & 102 & 34 & 55 & $-0.06 \pm 0.04$ & 1.37 & -1.31 \\
\hline & 4 & 27 & 15 & 12 & $0.17 \pm 0.04$ & 0.86 & -0.9 \\
\hline & 5 & 101 & 26 & 72 & $-0.5 \pm 0.11$ & 0.92 & -5.26 \\
\hline & 6 & 86 & 22 & 60 & $-0.36 \pm 0.19$ & 0.66 & -1.54 \\
\hline & 7 & 168 & 81 & 84 & $0.27 \pm 0.12$ & 5.71 & -6.35 \\
\hline & 8 & 38 & 22 & 15 & $0.008 \pm 0.003$ & 0.88 & -1.2 \\
\hline & 9 & 76 & 15 & 60 & $-0.3 \pm 0.04$ & 0.87 & -0.9 \\
\hline & 10 & 41 & 31 & 10 & $1.48 \pm 1.08$ & 4.32 & -1.14 \\
\hline & 11 & 58 & 37 & 17 & $0.65 \pm 0.48$ & 8.48 & -1.94 \\
\hline & 12 & 133 & 95 & 38 & $0.61 \pm 0.17$ & 3.61 & -0.79 \\
\hline & 13 & 67 & 67 & - & $5.9 \pm 2.57$ & 9.87 & 0.89 \\
\hline & 14 & 203 & 140 & 51 & $0.77 \pm 0.29$ & 10.46 & -1.55 \\
\hline & 15 & 123 & 50 & 59 & $0.003 \pm 0.001$ & 1.44 & -1.61 \\
\hline 2 & & 235 & 134 & 95 & $1.31 \pm 1.11$ & 7.29 & -2.39 \\
\hline \multirow{2}{*}{3} & 1 & 33 & 19 & 14 & $0.29 \pm 0.10$ & 2.24 & -1.62 \\
\hline & 2 & 125 & 114 & 10 & $7.86 \pm 4.47$ & 25.91 & -2.28 \\
\hline 4 & & 82 & 77 & 3 & $6.48 \pm 4.95$ & 18.67 & -0.64 \\
\hline \multirow{3}{*}{5} & 1 & 17 & 17 & - & $11.01 \pm 7.58$ & 20.23 & 0.01 \\
\hline & 2 & 41 & 39 & 2 & $9.75 \pm 7.46$ & 22.21 & -0.83 \\
\hline & 3 & 81 & 35 & 39 & $40.4 \pm 0.22$ & 17.43 & -22.45 \\
\hline 6 & & 48 & 25 & 15 & $0.28 \pm 0.14$ & 3.41 & -0.69 \\
\hline \multirow{4}{*}{7} & 1 & 57 & 28 & 29 & $-0.42 \pm 0.20$ & 4.76 & -3.53 \\
\hline & 2 & 77 & 56 & 19 & $0.59 \pm 0.32$ & 10.48 & -3.91 \\
\hline & 3 & 93 & 42 & 45 & $0.05 \pm 0.02$ & 3.14 & -2.35 \\
\hline & 4 & 83 & 48 & 35 & $0.59 \pm 0.23$ & 4.97 & -3.84 \\
\hline 8 & & 47 & 18 & 29 & $-0.05 \pm 0.01$ & 2.85 & -2.46 \\
\hline \multirow{2}{*}{9} & 1 & 77 & 38 & 38 & $-0.44 \pm 0.27$ & 2.99 & -9.27 \\
\hline & 2 & 70 & 38 & 30 & $-0.12 \pm 0.10$ & 3.86 & -3.39 \\
\hline 10 & & 85 & 21 & 64 & $-0.44 \pm 0.28$ & 7.06 & -5.76 \\
\hline
\end{tabular}

Moving eastward approaching the Mehran river estuary and located at Mardo Island, Zone 2 progressed toward the sea at an average rate of $1.31 \pm 2.71 \mathrm{~m} \mathrm{yr}^{-1} ; 134$ of 235 transects $(57 \%)$ expanded their boundaries with a maximum expansion rate of $7.29 \mathrm{~m} \mathrm{yr}^{-1}$ (Table 2 and Figure 2). Zones 3 through 6, located in the estuaries of Kohneh-shahr, Minab and Nakhl-e-Ziarat, expanded their boundaries through sedimentation in the vast majority of transects. Zone 5-Sites 1 and 2, with respective marginal lengths of 3.56 and $5.49 \mathrm{~km}$, had the highest rates of boundary expansion or sedimentation (11.01 $\pm 7.58 \mathrm{~m} \mathrm{yr}^{-1}$ and $9.75 \pm 7.46 \mathrm{~m} \mathrm{yr}^{-1}$, respectively) among all of the regions investigated in this study. Zone 5-Site 3, which has a marginal length of $1.25 \mathrm{~km}$, showed the greatest boundary contraction $(-22.45 \mathrm{~m} \mathrm{yr}$ ${ }^{1}$ ) in this study; in contrast, Zone 3-Site 2, which has a marginal length of $1.8 \mathrm{~km}$, showed the greatest boundary expansion (25.91 $\mathrm{m} \mathrm{yr}^{-1}$ ) (Table 2 and Figure 2). Zone 7 with its four sites located in the vicinity of the Nakhleziarat and Kartan river estuaries and a total marginal length of $25.37 \mathrm{~km}$, mostly (except for Site 1) expanded its boundaries by sedimentation and progressed toward the sea (Table 2 and Figure 3). The greatest boundary dynamics in Zone 7 were found in Site 2 that exhibited the greatest expansion $\left(10.46 \mathrm{~m} \mathrm{yr}^{-1}\right)$ and the greatest contraction $\left(-3.91 \mathrm{~m} \mathrm{yr}^{-1}\right)$. 


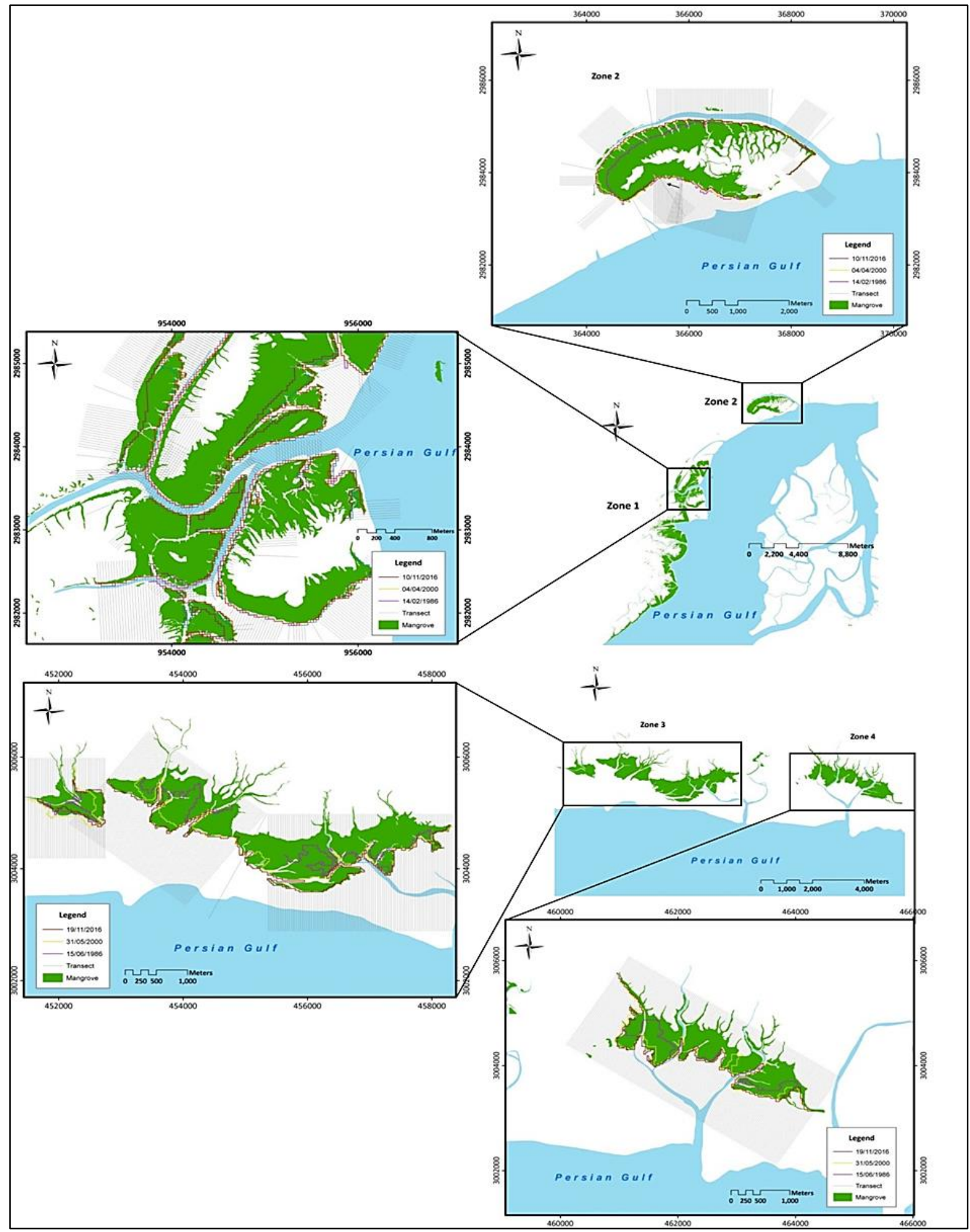

Figure 2. Shorelines changes of mangroves in Khamir habitat during 30-year period

Zone 8, located between the Roubahi estuary and adjacent to the port of Jask, had a marginal length of $2.82 \mathrm{~km}$ and exhibited minor average boundary contractions of $-0.05 \pm 0.01 \mathrm{~m} \mathrm{yr}^{-1}$; even though the boundaries contracted on the majority of transects indicating the dominance of erosion processes, boundaries on individual transects expanded up to $2.85 \mathrm{~m} \mathrm{yr}^{-1}$ and contracted up to $-2.46 \mathrm{~m} \mathrm{yr}^{-1}$. Zones 9 and 10, which comprise the easternmost mangrove sites in Iran and are located at the estuary of the Shahre-Nu River and at the coast of the Kashani River, respectively, experienced overall boundary regression and erosion processes, despite receiving sediment inputs from these rivers. Whereas the numbers of transects with expanding and contracting boundaries were more even in Zone 9, 75\% of transects in Zone 10 showed contracting boundaries and dominance of erosion processes; the most severe contractions observed were $9.27 \mathrm{~m} \mathrm{yr}^{-1}$ in Zone 9 and $-5.76 \mathrm{~m} \mathrm{yr}^{-1}$ in Zone 10 (Table 2 and Figure 3). Changes in average boundary movements along the northern coasts of the Persian Gulf and the Oman Sea indicate an overall spatial trend that underscores the dynamic condition of these coastal areas. In general, the dynamics in Zone 1 were dominated by erosion in sites 1 to 9; 
in contrast, sedimentation dominated in Zone 1 between Sites 10 and 15 and in Zones 2 to 6 Whereas Zone 7 was dominated by sedimentation processes, Zones 8 to 10 exhibited erosion of substrates and inland movement of the boundary (Table 2 and Figure 4).

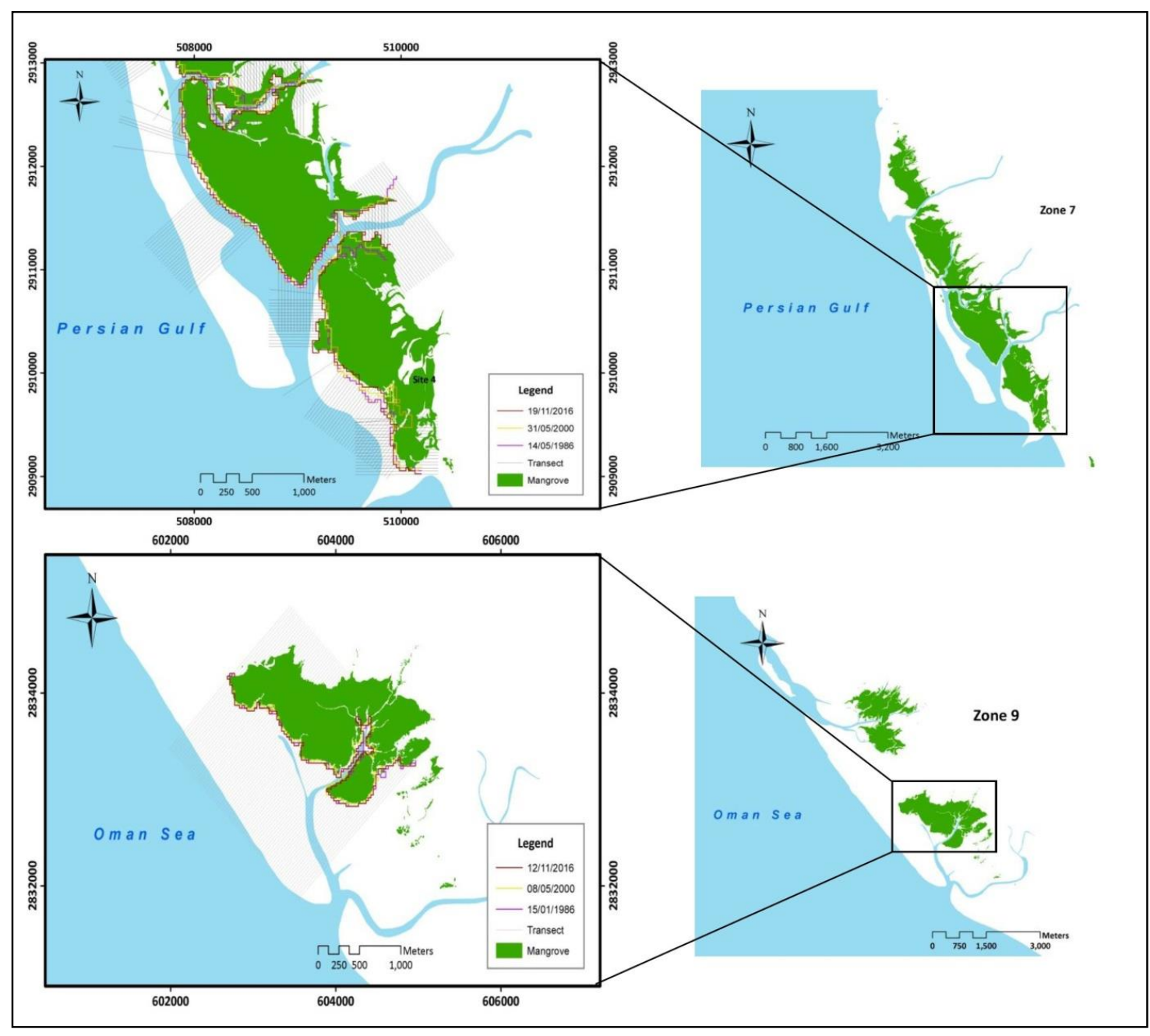

Figure 3. Shorelines changes of mangroves in Tiab habitat during 30-year period

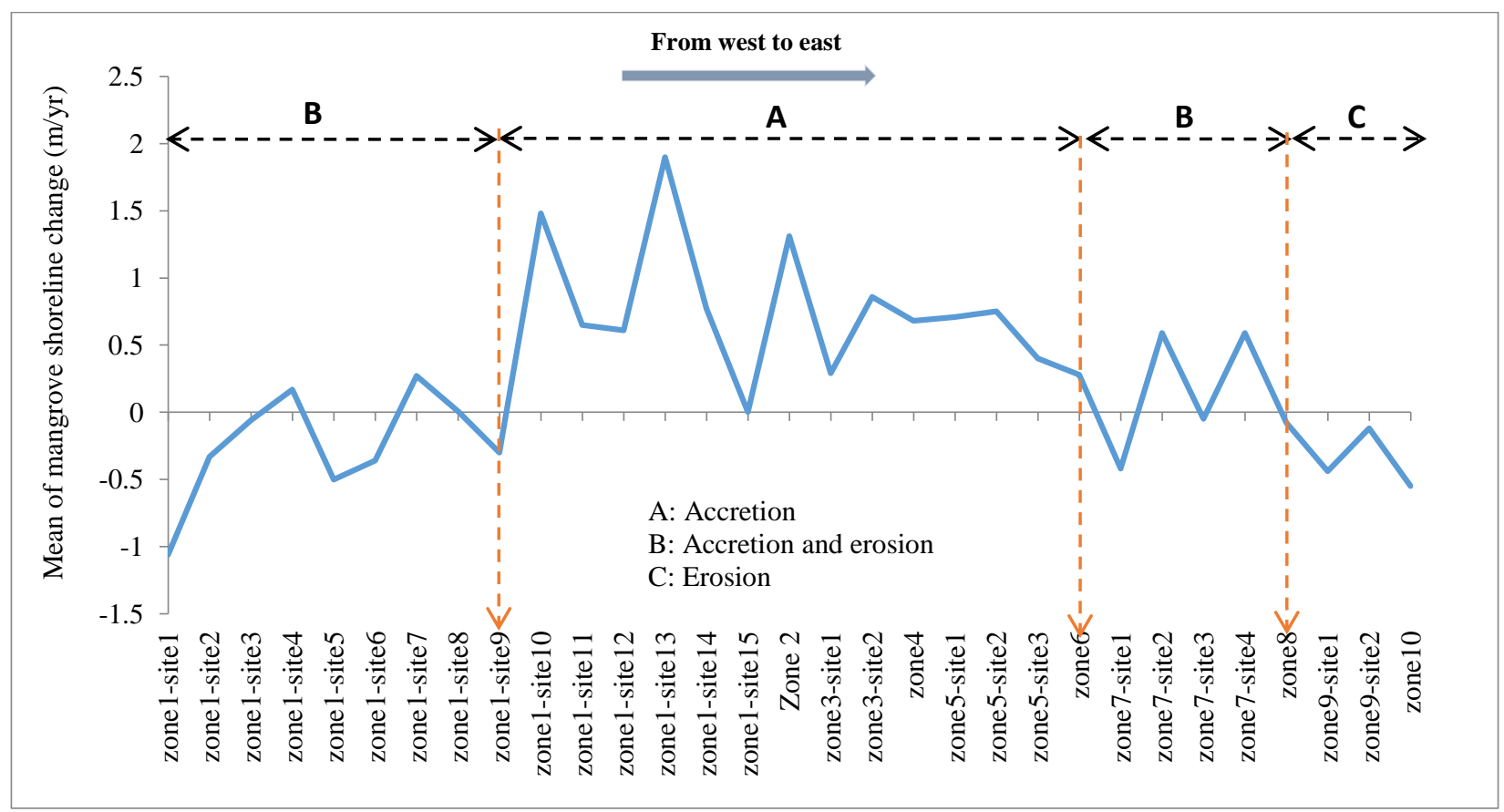

Figure 4. Mangrove boundary changes from the West to the East coasts of the Hormozgan province 


\section{4- Discussion}

Investigating the spatial changes of the boundaries of mangrove forests on the coasts of the Persian Gulf and Oman Sea over a period of 30 years clearly revealed that the coastal boundaries formed by mangrove ecosystems are not static over time, but are characterized by dynamic contractions and expansions that are highly variable in space. In this study, we did not find a systematic contraction of mangrove forests throughout the entire study area; rather, within a general gradient of increased contraction from west to east, different zones and sites within the study area exhibited differential rates of progression and regression of mangrove boundaries. In the areas where boundaries contracted, the average rate of contraction of Iranian mangrove forests of $-0.38 \mathrm{~m} \mathrm{yr}^{-1}$ (ranging between $-0.05 \mathrm{~m} \mathrm{yr}^{-1}$ in Zone 8 to $-1.26 \mathrm{~m} \mathrm{yr}^{-1}$ in Zone 1) are lower than what has been reported from other mangrove ecosystems around the world. Over a 32-year period (1975-2007), mangrove forests of the Douala Estuary in Cameroon had an average regression rate of $-3 \mathrm{~m} \mathrm{yr}^{-1}$ [23]. In American Samoa, an average erosion rate of $-1.11 \mathrm{~m} \mathrm{yr}^{-1}$ (ranging from $-0.06 \mathrm{~m} \mathrm{yr}^{-1}$ to $-3.27 \mathrm{~m} \mathrm{yr}^{-1}$ ) was documented for a 40-year period (1961-2001) [14] and mangrove forests of Mui Ca Mau, Vietnam regressed on average by -33.24 $\mathrm{m} \mathrm{yr}^{-1}$ (ranging from $-0.06 \mathrm{~m} \mathrm{yr}^{-1}$ to $-38.31 \mathrm{~m} \mathrm{yr}^{-1}$ ) over a 51-year period (1953-2011) [58]. The lower regression or erosion rates of mangrove forests in Iran may be a consequence of different sediment dynamics in our coastal environment as well as a multitude of other contributing factors that cause erosion, such as the construction and installation of structures in coastal areas, socio-economic issues, and specific climatic characteristics of the various regions of the world. In fact, studies have shown that many factors including changes in the distribution of sediments in coastal environments due to constructing infrastructures, over-exploitation of mangroves for fuel or grazing purposes, aquaculture development, contaminants and climate impacts such as rising sea levels are among the main factors implicated to cause contraction of mangrove forests in other parts of the world [14, 23, 56, 58]. In the mangrove forests of Iran, various factors such as grazing that are rampant in Zones 1, 8, 9 and 10, extraction of firewood and building materials, aquaculture development, construction of piers, marine transportation, movement of vessels in the mangrove areas, development of certain industries and mining around the mangroves, construction of dams and roads on rivers (Jagin dam), discharge of industrial and household waste from surrounding urban areas as well as oil pollution can play a major role in degradation and regression of these ecosystems [19, 20, 21].

Interviews with local people and experts of the Provincial Department of Natural Resources indicated a wide-held opinion that excessive use of mangrove forests by local indigenous peoples such as cutting mangrove branches to feed livestock also contributes in the destruction of these sites. Further, the interviewees stated that price increases of oil and fuel materials following the implementation of the Iranian subsidy reform plan in 2012 precluded many of the lowincome households in villages surrounding the mangroves from meeting their fuel needs, which has led to increased cutting of mangrove branches. Undoubtedly, the uncontrolled exploitation of mangroves is a cause for significant decreases in the extent of mangrove forests and for erosion of substrates that may ultimately lead to increased vulnerability of these forests to other natural and human hazards.

The greatest contraction of mangroves observed in Zone 1 (Strait of Hormoz) is likely due to intensive construction and industrial activities, boat traffic, fishing activities, discharge of oil materials and industrial and domestic wastes that are particularly concentrated in this zone. The contraction of mangroves located on the shores of Oman Sea (Zones 8 and 10) is most likely due to the erosion of shallow and corroded marine facies that is prevalent especially at the mouth of the estuaries. Here, the Jagin River flows in basins adjacent to the Oman Sea through fast-erodible geological formations of the Makran formation. The Jagin River is one of the main rivers that drains the province and produces sedimentation in the sea. Tributaries of Jagin River that originate from the southern slopes of Makran and Bashargard mountains have a torrential flow regime that used to transport large volumes of sediments during rainfall events. The construction of Jagin dam on the Jagin River in 2008 significantly reduced the amount of sediment that enters the sea at the mouth of the river as evidenced by volumes of 5.2 million $\mathrm{m} 3$ of sediment retained annually by the dam. Undoubtedly, the construction of the dam has changed the sedimentary dynamics of coastal areas in downstream areas and is a contributing factor that explains the contraction of mangroves in this area. Decreased qualities and quantities of mangroves following large changes in volumes of water and sediment loads often follow the construction of dams that alter the flow path of rivers $[23,72,73,74]$, necessitating more detailed assessments of the impacts of the Jagin dam on contraction of mangroves in this area.

Average expansion rates of mangrove boundaries of $2.55 \mathrm{~m} \mathrm{yr}^{-1}$ in areas where progression was observed is inbetween but closer to the lower range reported for the Douala Estuary, Cameroon (0.79 $\left.\mathrm{m} \mathrm{yr}^{-1}\right)$ [23] and Mui Ca Mau, Vietnam (40.65 $\mathrm{m} \mathrm{yr}^{-1}$ ) [58]. The expansion in this study may be explained by the high rates of terrestrial soil erosion in the watersheds of the Hormozgan province that, according to studies by the Forests, Range and Watershed Management

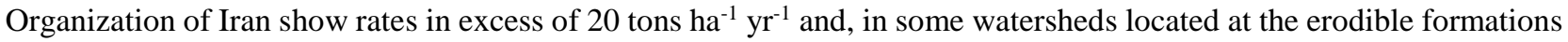
of Makran subduction, 30 tons $\mathrm{ha}^{-1} \mathrm{yr}^{-1}$. This high erosion volume is influenced by four main factors: a high-intensity shower rainfall regime, the presence of erodible geological formations particularly Makran marls and Mishan formations in the central and eastern parts of the province, the steep topography and slopes, and a low density of vegetation in the Hormozgan province [75]. On the coasts between the Minab estuary in the east and the Shour estuary in west of Bandar Abbas, surface flows of the Mehran, Minab, Shour, Kal, Hasan Langi, and Jalabi rivers erode shallow coastal beds and 
fore-banks of central and eastern regions of the province, leading to the extension of coastal plains and increased sedimentation in mangrove beds of these coastal areas. This might explain the greater rates of progression of mangroves in Zones 1 and 6 and a major part in Zone 7 compared with other regions. The expansion of the boundaries in Zones 3 through 6 is likely due to significant volumes of sediment loads that enter the estuaries of Kohneh-shahr, Minab and Nakhl-e-Ziarat from upstream basins. In addition to the significant role played by rivers, geological conditions between the axial extensions of folds relative to the coastline may also have contributed to increased amounts of sedimentation volumes in this region. Studies of aerial photographs and topographic maps show that fore-bank slope is an effective factor in high sedimentation in the central and eastern coasts [76].

\section{5- Conclusion}

Analysis of spatial variability of mangrove boundaries of the northern coast of the Persian Gulf and the Oman Sea revealed an average rate of expansion of mangrove boundaries of $2.55 \mathrm{~m} \mathrm{yr}^{-1}$ in areas characterized by progression and a contraction rate of boundaries of $-0.38 \mathrm{~m} \mathrm{yr}^{-1}$ in areas characterized by regression, with extreme values of $25.91 \mathrm{~m} \mathrm{yr}^{-}$ ${ }^{1}$ expansion and $-22.45 \mathrm{~m} \mathrm{yr}^{-1}$ contraction. The overall trend of movement of mangrove boundaries revealed dynamic changes along coastal mangroves on the Central Coast (West of the Strait of Hormoz in the Persian Gulf) that represented differential levels of progression and regression of boundaries, with overall eastward increases in progression and sedimentation rates of mangroves. Ultimately, in the easternmost part of the Oman Sea, mangroves were characterized by erosion or regression. Mangroves in Iran are influenced by a range of natural and human factors that can affect the conditions, growth trends, and development of mangroves in the northern coast of the Persian Gulf and the Oman Sea. Further studies are needed to show the extent to which each of these factors may affect the changes the boundaries of the mangrove ecosystems in these areas.

Our evaluation of the general trend in the average movement of mangrove boundaries along the coasts of the Hormozgan province indicated that the mangroves located at the coasts of the Persian Gulf exhibit spatially heterogeneous dynamics that include locally variable progression and/or regression of the boundaries. In general, the progression rate due to sedimentation in mangroves increases in an eastward direction (in the strait of Hormoz): on the eastern coasts of the Oman Sea, mangrove dynamics are mainly characterized by regression erosion processes. The results of this study clearly indicate that a spatially explicit analysis of mangrove boundaries using satellite images and GIS is a useful tool for monitoring and identifying the most vulnerable and erodible sites. Progression and regression rates of mangrove ecosystems located at the southern coasts of the Persian Gulf and the Oman Sea (along the coasts of Bahrain, Qatar, Kuwait, UAE, Oman and Saudi Arabia) could be estimated with the method used in this study to investigate whether a clearer trend in the direction of mangrove ecosystem expansion or contraction may be observed at a larger scale.

\section{6- Acknowledgements}

We are thankful to the Faculty of Natural Resources, University of Shahrekord, Iran for giving us this opportunity and facilities to carry out this study.

\section{7- Conflict of Interest}

The authors declare no conflict of interest.

\section{8- References}

[1] Barbier, Edward B. "Valuing Environmental Functions: Tropical Wetlands.” Land Economics 70, no. 2 (May 1994$)$ : 155. doi:10.2307/3146319..

[2] Barbier, Edward B, Mike Acreman, and Duncan Knowler. "Economic Valuation of Wetlands: A Guide for Policy Makers and Planners.” Gland, Switzerland: Ramsar Convention Bureau (January 1997). ISBN:2-940073-21-X.

[3] Kathiresan, K., and N. Rajendran. "Coastal Mangrove Forests Mitigated Tsunami.” Estuarine, Coastal and Shelf Science 65, no. 3 (November 2005): 601-606. doi:10.1016/j.ecss.2005.06.022.

[4] Wells, Sue, and Corinna Ravilious. "In the Front Line: Shoreline Protection and Other Ecosystem Services from Mangroves and Coral Reefs.” (2006). ISBN:92-807-2681-1.

[5] Tamin, N. M., R. Zakaria, R. Hashim, and Y. Yin. "Establishment of Avicennia Marina Mangroves on Accreting Coastline at Sungai Haji Dorani, Selangor, Malaysia." Estuarine, Coastal and Shelf Science 94, no. 4 (October 2011): $334-342$. doi:10.1016/j.ecss.2011.07.009.

[6] Hamilton, L. S., J. A. Dixon, and G. O. Miller. "Mangrove Forests: An Undervalued Resource of the Land and of the Sea." Ocean Yearbook Online 8, no. 1 (January 1989): 254-288. doi:10.1163/221160089X00146. 
[7] Kaplowitz, M. D. “Assessing Mangrove Products and Services at the Local Level: The Use of Focus Groups and Individual Interviews." Landscape and Urban Planning 56, no. 1-2 (September 2001): 53-60. doi:10.1016/S0169-2046(01)00170-0.

[8] Alongi, D. M. "Present State and Future of the World's Mangrove Forests." Environmental Conservation 29, no. 3 (September 2002): 331-349. doi:10.1017/S0376892902000231.

[9] Mumby, P. J., A. J. Edwards, J. E. Arias-González, K. C. Lindeman, P. G. Blackwell, A. Gall, and G. Llewellyn, G. "Mangroves Enhance the Biomass of Coral Reef Fish Communities in the Caribbean.” Nature 427, no. 6974 (February 2004): 533-536. doi:10.1038/nature 02286 .

[10] Nagelkerken, I. S. J. M., S. J. M. Blaber, S. Bouillon, P. Green, M. Haywood, L. G. Kirton, J-O. Meynecke, J. Pawlik, H. M. Penrose, A. Sasekumar, and P. J. Somerfield. "The Habitat Function of Mangroves for Terrestrial and Marine Fauna: A Review." Aquatic Botany 89, no. 2 (August 2008): 155-185. doi:10.1016/j.aquabot.2007.12.007.

[11] Kristensen, E., S. Bouillon, T. Dittmar, and C. Marchand. "Organic Carbon Dynamics in Mangrove Ecosystems: A Review." Aquatic Botany 89, no. 2 (August 2008): 201-219. doi:10.1016/j.aquabot.2007.12.005.

[12] Walters, B. B., P. Ronnback, J. M. Kovacs, B. Crona, S. A. Hussain, R. Badola, and F. Dahdouh-guebas. "Ethnobiology, Socioeconomic and Management of Mangrove Forests: A Review." Aquatic Botany 89, no. 2 (August 2008): 220-236. doi:10.1016/j.aquabot.2008.02.009.

[13] Souza Filho, P. W. M., E. D. S. F. Martins, and F. R. Da Costa. "Using Mangroves as A Geological Indicator of Coastal Changes in the Bragança Macrotidal Flat, Brazilian Amazon: A Remote Sensing Data Approach.” Ocean and Coastal Management 49, no. 7-8 (2006): 462-475. doi:10.1016/j.ocecoaman.2006.04.005.

[14] Gilman, E., and J. Ellison. And R. Coleman. "Assessment of Mangrove Response to Projected Relative Sea-Level Rise and Recent Historical Reconstruction of Shoreline Position.” Environtal Monitoring and Assessment 124, no. 1-3 (January 2007): 105-130. doi:10.1007/s10661-006-9212-y.

[15] McIvor, Carole, JA Ley, and Robin Bjork. "Changes in Freshwater Inflow from the Everglades to Florida Bay Including Effects on Biota and Biotic Processes: A Review.” Everglades: the Ecosystem and Its Restoration. St. Lucie Press, Delray Beach, (January 1, 1994): 117-146.

[16] FAO (Food and Agriculture Organization of the United Nations). "The World's Mangroves 1980-2005." FAO Forestry Paper 153. FAO, Rome. (2007).

[17] Spalding, Mark, Mami Kainuma, and Lorna Collins. "World atlas of Mangroves.” Routledge. (2010).

[18] Danehkar, A. "Marine Sensitive Areas of Iran.” The Environment Scientific Quarterly Journal 24, (1998): 28-38.

[19] Danehkar, A. "Mangroves Forests Zonation in Gaz and Harra International Wetlands." The Environment Scientific Quarterly Journal 34, (2001): 43-49.

[20] Mehrabian, A., A. Naqinezhad, A. S. Mahiny, H. Mostafavi, H. Liaghati, and M. Kouchekzadeh. "Vegetation Mapping of the Mond Protected Area of Bushehr Province (South-west Iran).” Journal of Integrative Plant Biology 51, no. 3 (2009): 251-260.

[21] Zahed, M. A., F. Rouhani, S. Mohajeri, F. Bateni, and L. Mohajeri. “An Overview of Iranian Mangrove Ecosystems, Northern Part of the Persian Gulf and Oman Sea." Acta Ecologica Sinica 30, no. 4 (August 2010): $240-244$. doi:10.1016/j.chnaes.2010.03.013.

[22] Ghasemi, S., M. Zakaria, H. Abdul-Hamid, E. Yusof, A. Danehkar, and M. N. Rajpar. "A Review of Mangrove Value and Conservation Strategy by Local Communities in Hormozgan Province, Iran.” Journal of American Science 6, no. 10 (2010): 329-338.

[23] Ellison, J. C., and I. Zouh. "Vulnerability to Climate Change of Mangroves: Assessment from Cameroon, Central Africa." Biology 1, no. 3 (November 2012): 617-638. doi:10.3390/biology1030617.

[24] Woodroffe, C. D. "Response of Tide-dominated Mangrove Shorelines in Northern Australia to Anticipated Sea-level Rise." Earth Surface Processes and Landforms 20, no. 1 (February 1995): 65-85. doi:10.1002/esp.3290200107.

[25] Solomon, S., J. Kruger, and D. Forbes. "An Approach to the Analysis of Storm-Surge and Sea-Level Vulnerability Using GIS: Suva, Fiji, South Pacific." In Proceedings of the 1997 Canadian Coastal Conference, (May 1997). Canadian Coastal Science and Engineering Association, Ottawa, Canada.

[26] El-Raey, M., O. Frihy, S. Nasr, and K. Dewidar. "Vulnerability Assessment of Sea Level Rise Over Port Said Governorate, Egypt.” Environmental Monitoring and Assessment 56, no. 2 (May 1999): 113-128. doi:10.1023/A:1005946819600.

[27] White, K., and H. M. El Asmar. "Monitoring Changing Position of Coastlines Using Thematic Mapper Imagery, An Example from the Nile Delta." Geomorphology 29, no. 1-2 (August 1999): 93-105. doi:10.1016/S0169-555X(99)00008-2.

[28] Saintilan, N., and K. Wilton. "Changes in the Distribution of Mangroves and Saltmarshes in Jervis Bay, Australia." Wetlands Ecology Management 9, no. 5 (October 2001): 409-420. doi:10.1023/A:1012073018996. 
[29] Cohen, M. C., and R. J. Lara. "Temporal Changes of Mangrove Vegetation Boundaries in Amazonia: Application of GIS and Remote Sensing Techniques." Wetlands Ecology Management 11, no. 4 (August 2003): $223-231$. doi:10.1023/A:1025007331075.

[30] Dahdouh-Guebas, F., E. Van Hiel, J. C. W. Chan, L. P. Jayatissa, and N. Koedam. "Qualitative Distinction of Congeneric and Introgressive Mangrove Species in Mixed Patchy Forest Assemblages Using High Spatial Resolution Remotely Sensed Imagery (IKONOS)." Systematics and Biodiversity 2, no. 2 (2004): 113-119. doi:10.1017/S1477200004001422.

[31] Fromard, F., C. Vega, and C. Proisy. "Half a Century of Dynamic Coastal Change Affecting Mangrove Shorelines of French Guiana. A Case Study Based on Remote Sensing Data Analyses and Field Surveys." Marine Geology 208, no. 2-4 (August 2004): 265-280. doi:10.1016/j.margeo.2004.04.018.

[32] Satyanarayana, B., K. A. Mohamad, I. F. Idris, M. L. Husain, and F. Dahdouh-guebas. "Assessment of Mangrove Vegetation Based on Remote Sensing and Ground-truth Measurements at Tumpat, Kelantan Delta, East Coast of Peninsular Malaysia." International Journal Remote Sensing 32, no. 6 (March 2011): 1635-1650. doi:10.1080/01431160903586781.

[33] Giri, C., E. Ochieng, L. L. Tieszen, Z. Zhu, A. Singh, T. Loveland, and N. Duke. "Status and Distribution of Mangrove Forests of the World Using Earth Observation Satellite Data." Global Ecology and Biogeography 20, no. 1 (August 2010): 154-159. doi:10.1111/j.1466-8238.2010.00584.x.

[34] Heumann, B. W. "An Object-based Classification of Mangroves Using a Hybrid Decision Tree-Support Vector Machine Approach.” Remote Sensing 3, no. 11 (2011): 2440-2460. doi:10.3390/rs3112440.

[35] Ahmad, S. R., and V .C. Lakhan. "GIS-based Analysis and Modeling of Coastline Advance and Retreat along the Coast of Guyana.” Marine Geodesy 35, no. 1 (March 2012): 1-15. doi:10.1080/01490419.2011.637851.

[36] Nfotabong-Atheull, A., N. Din, and F. Dahdouh-Guebas. "Qualitative and Quantitative Characterization of Mangrove Vegetation Structure and Dynamics in a Peri-urban Setting of Douala (Cameroon): An Approach Using Air-borne Imagery." Estuaries and Coasts 36, no. 6 (November 2013): 1181-1192. doi:10.1007/s12237-013-9638-8.

[37] Nguyen, H. H., C. McAlpine, D. Pullar, K. Johansen, and N. C. Duke. "The Relationship of Spatial-temporal Changes in Fringe Mangrove Extent and Adjacent Land-use: Case Study of Kien Giang Coast, Vietnam.” Ocean and Coastal Management 76, (May 2013): 12-22. doi:10.1016/j.ocecoaman.2013.01.003.

[38] Thieler, E. R., E. A. Himmelstoss, J. L. Zichichi, and A. Ergul. "Digital Shoreline Analysis System (DSAS) Version 4.0-An ArcGIS Extension for Calculating Shoreline Change.” US Geological Survey Open File Report, No. 2008-1278 (2009).

[39] Morton, R. A., and T. L. Miller. "National Assessment of Shoreline Change, Part 2: Historical Shoreline Changes and Associated Coastal Land Loss Along the US Southeast Atlantic Coast.” US Geological Survey Open File Report, No. 2005-1401 (2006).

[40] Thieler, E. R., and W. W. Danforth. "Historical Shoreline Mapping (II): Application of the Digital Shoreline Mapping and Analysis Systems (DSMS/DSAS) to Shoreline Change Mapping in Puerto- Rico.” Journal of Coastal Research 10, no. 3 (1994): 600-620.

[41] Hapke, C. J, D. Reid, B. M. Richmond, P. Ruggiero, and J. List. "National Assessment of Shoreline Change, Part 3: Historical Shoreline Change and Associated Coastal Land Loss Along Sandy Shorelines of the California Coast." US Geological Survey Open File Report No. 2006-1219 (2006).

[42] Mangham, W., and H. Williams. "GPS-based Analysis of Shoreline Change, 1995-2005, Mad Island Marsh Preserve, Matagorda County, Texas.” Texas Journal of Science 59, no. 1 (February 2007): 61-72.

[43] Hapke, C. J., and D. Reid. "National Assessment of Shoreline Change, Part 4: Historical Coastal Cliff Retreat Along the California Coast.” US Geological Survey Open-file Report (2007).

[44] Appeaning A. K., M. Walkden, and J. P. Mills. "Detection, Measurement and Prediction of Shoreline Recession in Accra, Ghana." Journal of Photogrammetry and Remote Sensing 63, (2008): 543-558.

[45] Thao, P. T. P., H. D. Duan, and D. V. To. "Integrated Remote Sensing and GIS for Calculating Shoreline Change in Phan Thiet Coastal Area.” International Symposium on Geoinformatics for Spatial Infrastructure Development in Earth and Allied Sciences, Hanoi, Vietnam. (2008): 1-6.

[46] Esteves, L. S., J. J. Williams, A. Nock, and G. Lymbery. "Quantifying Shoreline Changes Along the Sefton Coast (UK) and the Implications for Research-informed Coastal Management.” Journal of Coastal Research 56, no. 56 (January 2009): 602-606.

[47] Hapke, C. J., D. Reid, and B. Richmond. "Rates and Trends of Coastal Change in California and the Regional Behavior of the Beach and Cliff System.” Journal of Coastal Research 25, no. 3 (May 2009): 603-615. doi:10.2112/08-1006.1.

[48] Lisa, C., J. P. Walsh, and C. D. Reide. "Analyzing Estuarine Shoreline Change: A Case Study of Cedar Island, North Carolina." Journal of Coastal Research 26, no. 5 (September 2010): 817-830. doi:10.2112/JCOASTRES-D-09-00117.1. 
[49] Hapke, C. J., E. A. Himmelstoss, M. G. Kratzmann, J. H. List, and E. R. Thieler. "National Assessment of Shoreline Change: Historical Shoreline Change along the New England and Mid- Atlantic Coasts.” US Geological Survey Open File Report (2010).

[50] Cowart, L., D. R. Corbett, and J. P. Walsh. "Shoreline Change along Sheltered Coastlines: Insights from the Neuse River Estuary, NC, USA.” Remote Sensing 3, no. 7 (July 2011): 1516-1534. doi:10.3390/rs3071516.

[51] Rahman, A. F., D. Dragoni, and B. El-Masri. "Response of the Sundarbans Coastline to Sea Level Rise and Decreased Sediment Flow: A Remote Sensing Assessment." Remote Sensing Environment 115, no. 12 (December 2011): 3121-3128. doi:10.1016/j.rse.2011.06.019.

[52] Alberico, I., V. Amato, P. P. C. Aucelli, B. D’Argenio, G. D. Paola, and G. Pappone. "Historical Shoreline Change of the Sele Plain (Southern Italy): The 1870-2009 Time Window.” Journal of Coastal Research 28, no. 6 (August 2012): $1638-1647$. doi:10.2112/JCOASTRES-D-10.00197.1.

[53] Kuleli, T., A. Guneroglu, F. Karsli, and M. Dihkan. "Automatic Detection of Shoreline Change on Coastal Ramsar Wetlands of Turkey.” Ocean Engineering 38, no. 10 (July 2011): 1141-1149. doi:10.1016/j.oceaneng.2011.05.006.

[54] Sheik, M., and B. Chandrasekar. "A shoreline Change Analysis along the Coast between Kanyakumari and Tuticorin, India, Using Digital Shoreline Analysis System.” Geo-spatial Information Science 14, no. 4 (December 2011): $282-293$. doi:10.1007/s11806-011-0551-7.

[55] Natesan, U., N. Thulasiraman, K. Deepthi, and K. Kathiravan. "Shoreline Change Analysis of Vedaranyam Coast, Tamil Nadu, India.” Environtal Monitoring Assessment 185, no. 6 (June 2013): 5099-5109. doi:10.1007/s10661-012-2928-y.

[56] Hai-Hoa, N., C. McAlpine, D. Pullar, K. Johansen, and N. C. Duke. "The Relationship of Spatial-Temporal Changes in Fringe Mangrove Extent and Adjacent Land-use: Case Study of Kien Giang Coast, Vietnam." Ocean and Coastal Management 76, (May 2013): 12-22. doi:10.1016/j.ocecoaman.2013.01.003.

[57] Sarwar, M. G. M., and C. D. Woodroffe. "Rates of Shoreline Change along the Coast of Bangladesh." Journal of Coast Conservation 17, no. 3 (September 2013): 515-526. doi:10.1007/s11852-013-0251-6.

[58] Tran Thi, V., A. Tien Thi Xuan, H. Phan Nguyen, F. Dahdouh-Guebas, and N. Koedam. “Application of Remote Sensing and GIS for Detection of Long-Term Mangrove Shoreline Changes in Mui Ca Mau, Vietnam.” Biogeosciences 11, no. 14 (July 2014): 3781-3795. doi:10.5194/bg-11-3781-2014.

[59] Kabuth, A. K., A. Kroon, and J. B. Pedersen. "Multi-decadal Shoreline Changes in Denmark.” Journal of Coastal Research 30 , no. 4 (2014): 714-728. doi:10.2112/JCOASTRES-D-13-00139.1.

[60] Kuenzer, C., P. Leinenkugel, M. Vollmuth, and S. Dech. "Comparing Global Land-cover Products-Implications for Geoscience Applications: An Investigation for the Trans-boundary Mekong Basin.” International Journal Remote Sensing 35, no. 8 (April 2014) 2752-2779. doi:10.1080/01431161.2014.890305.

[61] Konopczak, A. M., G. K. Manson, and N. J. Couture. "Variability of Coastal Change along the Western Yukon Coast." Geological Survey of Canada Open File Report Open F (2014). doi:10.4095/293788.

[62] Dolan, R., M. S. Fenster, and S. J. Holme. "Temporal Analysis of Shoreline Recession and Accretion.” Journal of Coastal Research 7, no. 3 (1991): 723-744.

[63] Seto, K. C., and M. Fragkias. "Mangrove Conversion and Aquaculture Development in Vietnam: A remote Sensing-based Approach for Evaluating the Ramsar Convention on Wetlands." Global Environmental Change 17, no. 3-4 (August-October 2007): 486-500. doi:10.1016/j.gloenvcha.2007.03.001.

[64] Vo, Q. T., N. Oppelt, P. Leinenkugel, and C. Kuenzer. "Remote Sensing in Mapping Mangrove Ecosystems - An Object-based Approach.” Remote Sensing 5, no. 1 (January 2013): 183-201. doi:10.3390/rs5010183.

[65] Crowell, M., B. C. Douglas, and S. P. Leatherman. "On Forecasting Future U.S. Shoreline Positions: A Test of Algorithms." Journal of Coastal Research 13, no. 4 (1997): 1245-1255.

[66] Coyne, M. A., C. H. Fletcher, and B. M. Richmond. "Mapping Coastal Erosion Hazard Areas in Hawaii: Observation and Errors." Journal of Coastal Research 28, (1999): 171-184.

[67] Honeycutt, M. G., M. Crowell, and B. C. Douglas. "Shoreline Position Forecasting: Impact of Storms, Rate Calculation Methodologies, and Temporal Scales.” Journal of Coastal Research 17, no. 3 (January 2001): 721-730. Issn:0749-0208.

[68] Genz, A. S., C. H. Fletcher, R. A. Dunn, L. N. Frazer, and J. J. Rooney. "The Predictive Accuracy of Shoreline Change Rate Methods and Alongshore Beach Variation on Maui, Hawaii." Journal of Coastal Research 23, no. 1 (2007): 87-105. doi:10.2112/05-0521.1.

[69] Kuleli, T. "Quantitative Analysis of Shoreline Changes at the Mediterranean Coast in Turkey." Environmental Monitoring and Assessment 167, no. 1-4 (August 2010): 387-397. doi:10.1007/s10661-009-1057-8. 
[70] Lucas, R. M., J. C. Ellison, A. Mitchell, B. Donnelly, M. Finlayson, and A. K. Milne. "Use of Stereo Aerial Photography for Quantifying Changes in the Extent and Height of Mangroves in Tropical Australia." Wetllands Ecology and Management 10, no. 2 (April 2002): 159-173. doi:10.1023/A:1016547214434.

[71] Shearman, P. L. "Recent Change in the Extent of Mangroves in the Northern Gulf of Papua, Papua New Guinea." Ambio 39, no. 2 (April 2010): 181-189. doi:10.1007/s13280-010-0025-4.

[72] Hashimoto, Takehiko. "Environmental Issues and Recent Infrastructure Development in the Mekong Delta: Review, Analysis and Recommendations with Particular Reference to Large-scale Water Control Projects and the Development of Coastal Areas." (2001). ISBN: 1864871806.

[73] Dahdouh-Guebas, F., L. P. Jayatissa, D. Di Nitto, J. O. Bosire, D. L. Seen, and N. Koedam. "How Effective Were Mangroves as a Defense against the Recent Tsunami?" Current Biology 15, no. 12 (June 2005): R443-R447. doi:10.1016/j.cub.2005.06.008.

[74] Koedam, Nico, and Farid Dahdouh-Guebas. "Ecological Quality Changes Precede Changes in Quantity in Mangrove Forests" Science (October 2008). http://sciencemag.org/cgi/eletters/319/5861/321.

[75] Forests, Range and Watershed Management Organization (FRWMO). (2016) Available online http://frw.org.ir/00/En/StaticPages/Page.aspx?tid=13238.

[76] Ports and Maritime Organization of Iran (PMO). "Report on the Stratigraphic of Coastal Areas of the Iran, Integrated Coastal Zone Management Plan of Iran” (2014). 